\title{
Position of HGB Land above HPL to be Waqf
}

\author{
Mira Novana Ardani' ${ }^{1}$, Ana Silviana ${ }^{2}$ \\ \{miranovana@yahoo.com ${ }^{1}$, silvianafhundip@gmail.com ${ }^{2}$ \} \\ ${ }^{1,2}$ Faculty of Law Diponegoro University, Prof. Sudharto, SH. Street Number 1 Semarang, Indonesia
}

\begin{abstract}
Waqf has an important role in increasing economic activity. Land is one of the waqf objects that are not moving. There are land rights arrangements that can be waqf. One of them is HGB land which stands on HPL land. What is the position of HGB land on HPL land if it is to be waqf, and what possibilities can occur from the legal action. This research uses a normative juridical approach. Normative juridical research has the meaning of research focused on examining the application of rules or norms in positive law. If seen from the provisions of the existing laws and regulations, HGB land which is above the HPL land is allowed to be waqf as long as it has obtained written permission from the HPL holder. There are various possibilities that occur if HBG land above the HPL is waqf. These possibilities can pose risks later on.
\end{abstract}

Keywords: Waqf, Land, HGB, HPL.

\section{Introduction}

An individual or together, a legal entity has the right to do legal actions against the land owned by him. To find out that the land is legally owned can be seen in the evidence it has, which is the certificate of land rights, there is the name of the right holder. Legal actions that can be carried out by those whose names are listed in the certificate such as selling their land, can lease to others for the land they own, can give to others, and can also endow their land for certain interests.

Unlike other legal actions, waqf have broad benefits. Even waqf has an important role in increasing economic activity. This is because waqf can reduce poverty in Indonesia. This is reinforced by the opinion of Dr. Raditya Sukmana who noted that the significance of the role of the government to accommodate the community in representing, according to him, there are at least four sectors that are worthy of being assisted by waqf, namely education (school construction), health (hospital), infrastructure ( roads, power plants, irrigation), and mosques. If these four sectors are financed with waqf, it is enough to help ease the burden on the government's APBN and be able to reduce poverty in Indonesia.[1]

In accordance with the provisions contained in Law Number 41 of 2004 concerning Endowments, Article 16 states that waqf property consists of immovable and movable objects. This immovable property includes: rights to land that have or have not been registered, buildings or parts of buildings that stand on land, plants and other objects related to land, ownership rights to units of flats, and immovable objects in accordance with the provisions sharia and applicable laws and regulations.

Land rights that can be waqf, in accordance with Government Regulation Number 42 of 2006 concerning the Implementation of Law Number 41 of 2004 concerning waqf, Article 17, namely: ownership rights to land whether or not registered; Hak Guna Bangunan (HGB), Hak 
Guna Usaha (HGU), or Hak Pakai on state land; HGB or Hak Pakai over Hak Pengelolaan (HPL) or Hak Milik must obtain written permission from the HPL or Hak Milik holder; ownership rights over the unit of flats.

In the national land law in Indonesia, land rights that do not have a term are only Hak Milik. HGU, HGB, and Hak Pakai all have a term. HGU the maximum tenure is thirty-five years, HGB the maximum thirty years, and Hak Pakai twenty-five years. In relation to waqf, Hak Milik contains the lowest risk compared to other land rights that have a time period.

Based on waqf objects in the form of immovable property which is in the form of land rights mentioned above, there are also HPL. Basically, HPL themselves are not rights to land as contained in Article 16 of the Undang-Undang Pokok Agraria (UUPA). HPL are the delegation of part of the authority of the State's Control Rights, so that HPL are not included in the group (type) of land rights. The authority contained in the State's Right to Control is sourced from the delegation (transfer of) authority of the Indonesian Nation's Rights in relation to the earth, water and space, while HPL is delegated in part to the exercise of authority from the State's Right to Control. Whereas land rights are classified as individual or individual rights which are hierarchically under the State's Right to Control.[2]

Although it is said that HPL are not included in any of the rights to land, but above HPL can be loaded with a right to land. Such as HGB that loaded HPL, and Hak Pakai that loaded HPL. An agreement must be made for the assignment of land rights over HPL. This is because there are differences in the subject matter of rights, duration, authority held between the holders of land rights and HPL.

In the Regulation of the Minister of Agrarian Affairs / Head of the National Land Agency Number 9 of 1999 Article 4 paragraph (2) states that the agreement on the use of land HPL are also required as one of the conditions for granting land rights over part of HPL to third parties. In addition, Article 3 paragraph (2) of the Minister of Home Affairs Regulation No. 1 of 1977 states that the surrender of the use of HPL by management rights to third parties must be accompanied by the writing of a written agreement.

Another thing that makes a written agreement is very important, because what is contained in the agreement determines the position for both parties (for holders of HPL, and holders of land rights on it), so that each party can know and implement their rights and obligations with well.

The agreement made by the two parties does not merely contain an element of civilization but must fulfill the element of legal certainty for the party making it. This agreement to hand over the use of the HPL is very essential, because by making the agreement on the transfer of the use of the HPL the respective parties, especially the holder of the HPL, cannot terminate unilaterally the use of the land by a third party, as long as the right to the land has not been granted end up. Therefore, the provisions of Article 3 paragraph (1) of the Minister of Domestic Affairs Regulation Number 1 of 1977 which is currently amended by the Regulation of the Minister of Agrarian Affairs / Head of the National Land Agency Number 9 of 1999 aims to provide legal protection for both parties, especially and especially third parties who use the land HPL.[2]

Based on the explanation described regarding these HPL, as well as the possibility of a land right standing on the HPL, it is certainly very interesting to study further. Especially if the rights contained above the HPL are waqf by the rights holders for social interests. What is the status of the HGB land on the HPL if it is waqf, as well as the possibility of what can happen from the legal action. 


\section{Research Methods}

A method is a way of working or working procedures to be able to understand the objects that are the target of the relevant knowledge. The method is a guide to the way a scientist learns and understands the steps faced.[3] While research is an activity to search, record, formulate and analyze to compile reports.[4]

This study uses a normative juridical approach. Normative juridical research has the meaning of research focused on examining the application of rules or norms in positive law.[5] Whereas normative jurisdiction itself has an understanding of approaches that use the positivist legis conception. This concept views the law as identical with written norms created and promulgated by authorized institutions or officials. This conception views law as a normative system that is independent, closed and independent of real community life. [6]

This writing uses secondary data. The secondary data includes official documents, library books, laws and regulations, scientific works, articles, and documents related to research material. The secondary legal material includes three parts, namely:

1. Primary legal material

Primary legal materials, namely binding legal materials. The primary legal material used in this study consists of statutory regulations, namely the Basic Agrarian Law (UUPA), Minister of Agrarian Affairs and Spatial Planning / Head of the National Land Agency, Waqf Law, Implementing Regulations for Waqf Acts, and legislation others who can support in this writing.

2. Secondary legal material

Secondary legal material, which provides an explanation of primary legal material, such as, research results, work from legal circles, and so on.

3. Tertiary legal material

Tertiary legal materials, namely materials that provide instructions and explanations for primary and secondary laws; Examples are encyclopedias, dictionaries, cumulative indexes and so on.

The method used in collecting data in this research is to do a literature study, which is collecting data by searching and studying library materials that can be in the form of research results, literature, scientific magazines, and others. The results of the study are presented in the form of descriptions arranged systematically, meaning that the secondary data obtained will be linked to one another according to the problem under study, so that as a whole is a unified whole in accordance with research needs.

\section{Theoritical Framework}

Waqf in Indonesia is not a legal act that is only known in Indonesia. People have known him for a long time. However, before the issuance of rules governing waqf, people who want to give their land for social purposes do not go the way by writing down their actions in writing, but only verbally between the endowment and the recipient.

The provisions of agrarian law have also regulated waqf. The regulation regarding waqf in the UUPA can be found initially in Article 5 UUPA, the agrarian law that applies to the earth, water and space is customary law, as long as it does not conflict with national and state interests, based on national unity, with Indonesian socialism and with the regulations contained in the UUPA with other laws and regulations, everything by heeding the elements that rely on religious law. In addition to Article 5, Article 14 and Article 49 of the UUPA also regulates the provisions of land intended for religious purposes. 
In Article 1 of Law Number 41 of 2004 Concerning Waqf, the definition of waqf is a legal act of wakif to separate and / or surrender a portion of his property to be used forever or for a certain period in accordance with his interests for the purposes of worship and / or general welfare according to sharia. The definition of waqf shows that there must be sincerity from the party who donates their property, in this case wakif to nazhir, is the party who receives the waqf property from waqf to be managed and developed according to its designation. Waqf are valid if implemented according to sharia, and waqf that have been pledged cannot be canceled.

The purpose of waqf, in accordance with Article 4, is to utilize waqf property in accordance with its function. The function of waqf is very socially intended, because according to Article 5, waqf functions to realize the potential and economic benefits of waqf property for the benefit of worship and to promote public welfare. To achieve the goals and functions of waqf, according to Article 22, waqf property can only be designated for:

1. Religious facilities and activities;

2. Educational and health facilities and activities;

3. Assistance to the poor, neglected children, orphans, scholarships;

4. Progress and improvement of the people's economy; and / or

5. Other public welfare advancements that are not in conflict with sharia and statutory regulations.

Implementation of waqf must fulfill the elements contained in Article 6, among others: waqf, nazhir, waqf property, pledge of waqf, allotment of waqf property, waqf period. For waqf property itself, in Article 15, it is distinguished according to its type, whether it is included in the type of immovable property, or movable objects other than money, and whether it enters into a movable type in the form of money.

Type of immovable property waqf, in Article 16, includes:

1. Land rights are in accordance with the provisions of the legislation both already and not yet registered;

2. Buildings or parts of buildings that stand on the ground;

3. Plants and other objects related to the soil;

4. Ownership rights for flats in accordance with statutory provisions;

5. Other immovable objects are in accordance with sharia principles and laws and regulations.

The said land rights are certainly related to what is contained in the provisions of agrarian law. Article 4 of the Basic Agrarian Law, in paragraph (2) states that land rights authorize the use of the land concerned, likewise the body of the earth and water and the space therein are only needed for interests directly related to the use of land it is within the limits according to the UUPA and other higher legal regulations.

Land that is individually controlled with primary land rights, namely Hak Milik, land use rights (HGU), building rights (HGB), and use rights (Hak Pakai), are called land rights. Generally, these land rights are granted by the state, in this case the National Land Agency. In addition to these lands in the National Land Law there are other lands which are also controlled by primary land rights, which are also included in the definition of land rights. Namely lands controlled by individual rights:

1. On customary land rights, obtained by the community members of the relevant customary law community, according to the applicable customary law, after being converted;

2. On community land, obtained by its citizens according to the adat law of the people concerned, after being converted; 
3. On land the HPL, which at the request of the relevant HPL holder, is granted by the state, in this case the National Land Agency, to the parties that need it;

4. On land that belongs to the forest area, which with the approval of the Minister of Forestry, is granted by the state, in this case the National Land Agency, to parties who need it for business activities that are not directly related to forest concession activities.

Waqf is the right to control land, but not the right to land. The subjects are not individuals or legal entities.[7]

In terms of its authority to control, there is a tendency to further detail the status of lands which were originally included in the definition of state lands, to:[7]

1. Waqf lands, is land that has been represented;

2. Land of management rights, is lands which are controlled with management rights, which constitute the delegation of the implementation of a part of the authority of the controlling right from the state to the holders of their rights;

3. Customary land rights, is land held by territorial customary communities with customary rights;

4. Private lands, is land together with genealogical customary law communities;

5. Forest land lands, which are controlled by the Ministry of Forestry under the Basic Forestry Law. This power of ownership is also essentially a delegation of a part of the authority of the state's controlling right;

6. The remaining lands, namely lands controlled by the state, which are not private lands, not waqf lands, are not HPL, are not communal rights, are not communal lands, and are not lands. forest land area. These lands are lands that are truly directly controlled by the state, or are called state lands. Its control is carried out by the National Land Agency.

From the explanation above, HPL are not included in land rights. This can be seen from the understanding that is also contained in Article 1 number 2 of Government Regulation Number 40 of 1996 , namely the right to control the state whose authority is partially delegated to the holder. A more complete understanding of HPL is stated in the explanation of Article 2 paragraph (3) letter f of Law Number 20 of 2000 concerning Amendment to Law Number 21 of 1997 concerning Fees for Obtaining Land and Building Rights (BPHTB), Article 1 Regulation Government Number 36 of 1997 concerning Imposition of Fees for Acquisition of Rights to Land and Buildings Due to Granting of HPL, which are declared no longer valid by Article 1 Government Regulation Number 112 of 2000 concerning Imposition of Fees for Acquisition of Rights to Land and Buildings due to Granting of HPL, namely the right to control a state on land whose authority to implement is partially delegated to the right-holder to plan the designation and use of the land, use the land for the purposes of carrying out its duties, hand over parts of the land HPL to third parties and / or cooperate with third parties. [8]

From the understanding of management rights, it shows that:[8]

1. HPL are rights to control the state over land, not rights to land;

2. HPL are devolution of some authority from the state's right to control land;

3. Authority in HPL, is planning the designation and use of land, using the land for the purposes of carrying out its duties, and surrendering parts of the land management rights to third parties and / or cooperating with third parties.

Parties that can be subject or holders of HPL, namely subjects or holders of HPL are limited to government legal entities, both those engaged in the field of public service (government) or those engaged in business, such as State-Owned Enterprises / State-Owned Enterprises Daerah, PT Persero. Private legal entities do not get the opportunity to act as subjects or holders of HPL.[9] In addition, regarding the subject of HPL, it can refer to Article 
67 of the Regulation of the Minister of Agrarian Affairs / Head of the National Land Agency Number 9 of 1999, legal entities that can be granted HPL, namely:

1. Government agencies including local governments;

2. State Owned Enterprises (BUMN);

3. Regionally Owned Enterprises (BUMD);

4. PT Persero;

5. Authority

6. Other government legal entities appointed by the government.

The existence of waqf itself if we look at the provisions contained in the UUPA, have been accommodated in Article 49, namely:

1. Land rights of religious and social bodies insofar as they are used for business in religious and social fields, are recognized and protected. The agency is also guaranteed to obtain sufficient land for buildings and businesses in the religious and social fields.

2. For the purposes of worship and other holy purposes as referred to in Article 14, land can be directly controlled by the state with Hak Pakai.

3. Waqf land ownership is protected and regulated by government regulations.

Based on these provisions, it implies that land matters are closely related to worship and other sacred needs, one of which is land waqf, which in national agrarian law receives attention.[10]

\section{Results and Discussion}

Waqf as a means for people to be able to do charity, share with others, whose form can be in the form of movable or immovable objects. Elucidation of Law No. 41 of 2004 concerning Waqf says that one of the strategic steps to improve public welfare is the need to increase the role of waqf as a religious institution that is not only aimed at providing religious and social facilities, but also has potential economic strength, to advance welfare general, so that the utilization needs to be developed in accordance with sharia principles.

Although in its development the wakif can also waqf a portion of its noble wealth, securities, vehicles, intellectual property rights, lease rights, and other movable objects, but no less important is waqf in the form of immovable property namely land. To build a mosque, mosque, hospital and other buildings designated for activities above for social purposes certainly require land.

Only land with Hak Milik and Hak Pakai are owned by government agencies and are used for certain interests that do not have a time limit on their use and control. However, the regulation contained in Government Regulation Number 42 Year 2006 Concerning the Implementation of Law Number 41 Year 2004 Concerning Waqf, Article 17 says that in addition to ownership rights, other Hak Milik with a term can also be represented. No exception to Building Rights (HGB), and HGB above HPL. The provisions of Article 17 also state that HGB above HPL must obtain written permission from the HPL holder.

This is also confirmed by the provisions contained in the Regulation of the Minister of Agrarian Affairs and Spatial Planning / Head of the National Land Agency Number 2 of 2017 concerning Procedures for Registration of Waqf in the Ministry of Agrarian Affairs and Spatial Planning / National Land Agency. Article 3 paragraph (1) states that land that can be represented in the form of one HGB on HPL land. Paragraph (3) states that in the case of HGB land on HPL land, if it is to be represented forever, it must first obtain written permission or release from the HPL holder. Referring to Article 25 letter d of the Regulation of the Minister of Religion Number 73 of 2013 concerning Procedures for the Waqf of Immovable and 
Movable Non-Money Objects, for HGB on State Land which has obtained approval for the release of rights from the authorized official in the land sector, is registered as waqf land on behalf of Nazhir.

The status of HGB land above HPL land as described in the regulation is allowed to become waqf land. Of course, to get legal certainty and get legal protection, the HGB land that stands on the HPL land needs to be recorded and registered at the Land Office. In Article 9 of the Regulation of the Minister of Agrarian Affairs and Spatial Planning / Head of the National Land Agency Number 2 of 2017 Regarding Waqf, waqf land in the form of HGB over HPL is registered as waqf land in the name of Nazhir. The application for registration is accompanied by:

1. Application letter;

2. Measuring letter;

3. HGB certificate concerned;

4. Endowment Pledge Deed (AIW) or Substitute Deed Endowment Pledge (APAIW);

5. Release license from the HPL holder;

6. Nazir ratification letter concerned from the agency that conducts religious affairs at the district level, and;

7. A statement from Nazhir that the land is not in dispute, case, confiscation and is not guaranteed.

The Head of the Land Office issues the waqf certificate in the name of Nazhir, and records it in the land book and land title certificate in the column provided. In Article 9 paragraph (3) of the Regulation of the Minister of Agrarian Affairs and Spatial Planning / Head of the National Land Agency Number 2 of 2017 Concerning Waqf, the column contains: "The right to land is deleted based on the Waqf Pledge Deed / Substitute Deed Waqf Deed dated ... Number ... and issued certificate of land waqf number ... / ... according to the letter measuring date ... Number ... area ... m2".

Although the position of HGB land which is on HPL land is permitted and regulated in the law, but in the future implementation there may still be possibilities in the form of things that need to be anticipated from the transfer of HGB that stands on HPL land along with the risks.

Earlier before the issuance of Law Number 41 of 2004 Concerning Waqf, actually there was a regulation in the form of a Government Regulation governing Ownership Waqf, namely Government Regulation Number 28 of 1977. In the regulation there were no land other than Hak Milik that could be used as objects waqf land. Especially HGB land which is above the HPL land. The development of waqf is increasingly evident with the ratification of the Compilation of Islamic Law (KHI) through Presidential Instruction Number 1 of 1991. In this KHI, the issue of waqf has a special place, namely in book III. The content of the third book which consists of five chapters and 14 articles (215-228) adopts many Government Regulations No. 28 of 1977. Among them is the definition of waqf which necessitates the perpetuation of these goods and within an unspecified period of time, Article 215. End XX century is a new chapter in the history of Indonesian waqf with the emergence of the discourse of money waqf which then crystallizes into the desire to reform the legal waqf. This desire was realized with the birth of the Waqf Law Number 41 of 2004.[11]

The regulation states that the waqf of the land Hak Milik is a legal act of a person or legal entity separating part of his assets in the form of owned land and institutionalizing it for ever in the interests of worship or other public interests in accordance with the teachings of Islam.

Waqf Hak Milik considered safer. It is not without reason, because Hak Milik are special compared to other land rights. In Article 20 of the UUPA it is stated that ownership rights are 
hereditary, strongest and most fully owned rights to people over land. The explanation of the article is to show that among land rights, ownership rights are "ter" - (in the sense of "most") strong and "full". Namely regarding the absence of a time limit of land tenure and the broad scope of its use, which includes both to be worked on or used as a place to build something. [7]

In addition to these reasons, according to Boedi Harsono, only ownership rights can be waqf. That possibility is mentioned in Article 49 of the UUPA.[7] Taufiq Hamami also said that land that can be represented is land with the status of Hak Milik, because it has the strongest and most fulfilled character for the land owner, so from that nature the land owner is not bound by certain grace periods and conditions with ownership and use. Therefore, if the land is represented, it does not cause consequences that can interfere with the nature and permanence of the waqf institutional land.[12]

Basically, in accordance with the provisions contained in Article 18 of Government Regulation Number 42 of 2006 concerning the Implementation of Law Number 41 of 2004 concerning Waqf that immovable property in the form of land can only be represented for a period of time. However, there are exceptions to the waqf of land rights contained in Article 17 paragraph (1) letter c, namely the HGB or Hak Pakai on HPL or Hak Milik must obtain written permission from the HPL holder or the Hak Milik.

The right to land whether Hak Milik, HGB or Hak Pakai that has been given on the HPL land does not mean to delete or lose the authority of the HPL holder. One of the authorities of an HPL holder is to plan the designation and use of the land concerned. Even though the third party holds the land rights, the use of the land by the third party is under the supervision of the HPL holder. The monitoring function aims to prevent the occurrence of irregularities in the use of land that is not in accordance with the planning and designation of land that has been determined by the HPL holder.[2]

The regulation regarding the exemption actually also has its own risk to the HGB land that stands on HPL land if the holder of the HGB land does not openly declare that the land stands on HPL land. This cannot be denied if we see that there is still land conflict related to HGB land that stands on HPL land which is then misused by HGB holders by transferring its ownership to another party without the knowledge and permission of the HPL holder.

According to Arie Sukanti Hutagalung, the status of property developed on HPL land is indeed safe. However, even though it is safe, sometimes it makes it difficult for HGB owners. The reason is because those who want to extend, rent or sell must first obtain the approval of the HPL owner. In addition, the community or investors must also be careful that not all HPLs are clean and clear, and of disputes.[13]

In accordance with what is mentioned in Article 18 of Government Regulation Number 42 of 2006 concerning the Implementation of Law Number 41 of 2004 concerning Waqf, immovable waqf objects in the form of land can only be represented for a period of time. Determination of the perpetual period here to maximize the use of waqf property in order to provide benefits in accordance with sharia principles to advance public welfare certainly in the long term. However, in the provisions of Article 18 there are exceptions to the waqf period of HGB land over HPL land.

The period of waqf of HGB land over HPL that cannot last forever is a challenge in particular for nadzir. Nadzhir was given the trust to manage the waqf land and was given a time limit. It is not easy to manage and develop waqf property so that it is productive, especially with limited time. If the waqf property cannot function and develop according to its benefits, it will disappoint the wakif, because the wakif is the party that makes the donation of their property and hopes that what has been waqf can provide broad benefits to the community. 
In addition to the above risks, the subject of HPL holders is in accordance with Article 67 of the Regulation of the Minister of Agrarian Affairs / Head of the National Land Agency Number 9 of 1999, government agencies and legal entities owned by the government. This needs to be understood, considering that HPL is a controlling right from the state so that the state has the highest ownership rights as stipulated in Article 2 paragraph (1) of the UUPA giving to government agencies or legal entities with HPL.[2] The control of land owned by the government agency by HPL in general has a large amount. The Waqf land which stands on the HPL land must certainly be utilized in accordance with the purpose and function of waqf which had previously been stated in the act of waqf pledge deed.

Management and development of waqf property by Nazhir with vast land, requires hard work, as well as creative thinking of Nazhir and can innovate so that the waqf property that has been given by waqif can be managed and developed productively. This is in accordance with Article 43 of Law Number 41 Year 2004. It also requires the role of the Indonesian Waqf Board (BWI) to provide guidance to Nazhir in managing and developing the properties of the waqf. Reporting and supervision of waqf property is needed. The purpose of managing and developing waqf property is done productively, in the explanation of Article 43.

The procedure for reporting, Nazhir is required to submit reports of the management of waqf of assets to the Regional Office of the Ministry of Religion of the Province and BWI periodically every six months. The report covers the implementation of management, development, and use of the results of its management. This is contained in Article 28 of the Minister of Religion Regulation No. 73 of 2013 concerning Procedures for the Representation of Immovable Objects Apart from Money. The Head of the Regency / City Ministry of Religion Office is obliged to report the organization of endowments of immovable and movable objects other than money to the Head of the Provincial Ministry of Religion Regional Office periodically every six months. The Head of the Provincial Office of the Ministry of Religion submits the report to the Minister through the Director General periodically every six months. The regulation is contained in Article 29. Reports regarding the management of waqf assets, in accordance with Article 30, at least contain: types of waqf assets managed, forms of utilization of waqf assets, results of waqf property management, and use of the results of waqf property management.

In addition to starting from Nazhir, it is obligatory to provide reports to the Head of the Provincial Ministry of Religion's Regional Office, in the case of supervision it is necessary to make sure that the management of waqf property is already in accordance with its function and designation. Article 31 states that supervision of waqf is carried out by the ministry of religion and the community. Supervision carried out by the ministry of religion is carried out by direct examination of Nazhir for the management of waqf property. The supervision is coordinated by the Minister of Religion in this case the Director General.

Supervision of the management of waqf, in accordance with Article 32, at least includes: functions of waqf property, administration of waqf property management, development of waqf property, process of management of waqf property, results of management of waqf property, benefits of the results of the management of waqf property. Such supervision can be done through monitoring and evaluation of Nazhir reports, and / or checking written reports from the public. Written reports from the public are conveyed to the Office of the Ministry of Religion in Regency / City and / or BWI. After that, the submission of community reports is submitted to the Directorate General through the Provincial Ministry of Religion Regional Office. Article 35, the results of supervision conducted by the Ministry of Religion and the public are reported to the Minister and Chairperson of the Central BWI. If the results of the supervision show that Nazhir is proven to have committed a violation, then according to the 
provisions of Article 36, administrative sanctions are in accordance with the provisions of the laws and regulations.

\section{Conclusions}

The position of waqf of HGB land on HPL land has already been regulated in the provisions of the existing legislation, although initially only the land ownership rights can be represented. In order to obtain legal certainty guarantees, of course, HGB land on HPL land is registered in accordance with the waqf land registration procedures contained in the legislation.

The possibility that HGB land waqf can occur on HPL land, among others, the HGB land holder does not openly state that his land stands on HPL land. Nadzir, the management and development of waqf property by Nazhir with vast land, requires hard work, and Nadzir thinking that is creative and can innovate so that the waqf property that has been given by waqf can be managed and developed productively.

Acknowledgments. This research was supported by Faculty of Law Diponegoro University. We thank our colleagues from private law of Faculty of Law Diponegoro University who provided insight and expertise that greatly assisted the research.

\section{References}

[1] T. Tohor, "The Government's Role in BWI Development," in Delivered to BWI National Coordination Meeting, (2017).

[2] I. Soerodjo, Land Law on the Management of Land Rights (HPL) Existence, Regulation and Practice. Surabaya: Laksbang Mediatama, 2013.

[3] S. S. and S. Mamudji, Normative Legal Research A Brief Review, 1st ed. Jakarta: Raja Grafindo Persada, 2000.

[4] A. A. Cholid Narbuko, Research Methodology. Jakarta: Bumi Pustaka, 1997.

[5] J. Ibrahim, Theory and Methodology of Normative Legal Research. Malang: Banyumedia, 2006.

[6] R. H. Soemitro, No Title. Jakarta: Ghalia Indonesia, 1988.

[7] B. Harsono, Indonesian Agrarian Law, History of the Establishment of the Basic Agrarian Law Content and Its Implementation. Jakarta: Djambat, 2008.

[8] U. Santoso, Land Rights, Management Rights, and Property Rights in Flats. Surabaya: Kencana, 2017.

[9] Eman, "Management Right After the coming into force of the Regulation of the Minister of Agrarian Affairs / Head of National Land Agency Number 9 of 1999," Yuridika Magazine Faculty of Law Airlangga University, vol. 15, no. 3, Surabaya, p. 194, 2000.

[10] A. Sutedi, Transfer of Land Rights and Registration. Jakarta: Sinar Grafika, 2006.

[11] W. Hermawan, "Journal of Islamic-Ta'lim Religious Education," Polit. Law Endowments Indones., vol. 12, no. 2, p. 152, 2014.

[12] T. Hamami, Land Representation in the Politics of Agrarian Law. Ja: Tatanusa, 2003.

[13] H. B. Alexander, "HGB diatas HPL Aman Tetapi Menyulitkan," 2019. 